anhydride may combine with this water and so retard the final dehydration.

But, whatever may be the true explanation, it cannot be doubted that this obstinate retention by heated, and even fused, borax of about $0^{\circ} 2$ per cent. of water is the main cause of error in all previous attempts to determine the atomic weight of boron by means of this salt. That the conplete dehydration of borax is difficult was recognised by Dobrovolsky so far back as 1869, and was known to Hoskyns Abrahall, who concluded that the dehydration of borax was untrustworthy for ascertaining an atomic weight ratio.

In 1893 the late Sir William Ramsay and Miss Emily Aston published the results of a redetermination of the atomic weight of boron which appeared to them to confirm the commonly accepted value of $\mathrm{II}^{\circ} \mathrm{O}$. Their methods consisted (I) in ascertaining the water of crystallisation in borax, and (2) in converting dehydrated borax into sodium chloride by repeated distillation with hydrochloric acid and methyl alcohol, according to the process of Gooch and Rosenbladt. All the weighings are given in their paper to seven places of decimals-an assumption of precision scarcely warranted by the circumstances, and an instance of what Kopp was wont to call Decimalspielerei. The results of the first method varied from II 04 to $10: 85$; the mean value adopted was ro.92 I. Two series were made by the distillation method; the first gave values varying between II'OI5 and ro.879: adopted mean $=10^{\circ} 95^{2} ;$ in the second the extreme values were $10^{\circ} 99^{2}$ and $10^{\circ} 936$ : adopted mean 10.966. In the last series the amount of chlorine in the common salt was determined by gravimetric analysis in the usual way, which afforded a new ratio. The numbers thus obtained were uniformly above i I (II'003-II'09I : adopted mean $\mathrm{II}^{\circ} \mathrm{5}_{52}$ ).

The details given by Ramsay and Aston permit of a discussion of their observations in the light of the facts obtained by Messrs. Smith and van Haagen, and it is satisfactory to find that the two sets of observations can be brought into complete harmony. Indeed, certain inconsistencies among the results of the English observers, on which they themselves commented, but were unable to explain, are now cleared up, and serve to corroborate the results of the American chemists.

The recalculation of Ramsay and Aston's experimental numbers by means of the best-determined ratio of $\mathrm{AgCl}: \mathrm{NaCl}$ shows that the inconsistency referred to becomes slightly greater. From the weight of $\mathrm{NaCl}, \mathrm{B}=10^{\circ} 95^{\mathrm{I}}$; from that of $\mathrm{AgCl}, \mathrm{B}=\mathrm{I} \mathrm{I}^{\circ} 06 \mathrm{I}$, or a difference of fully $\mathbf{I}$ per cent. Now the method which they adopted to dehydrate borax combined with their low value for the density of vitreous borax- $-2 \cdot 29$, as against the proper value, $2: 357$-makes it practically certain that the fused borax still contained approximately $0: 3$ per cent. of water, and that the sodium chloride, although heated to $35^{\circ}$, still retained water the amount of which may be computed from the ratios. It was $0^{\circ} 2 \mathrm{I} 4$ per cent. By introducing these corrections, which are not arbitrary, but fully warranted by the facts, Ramsay and Aston's first series leads to the value $\mathrm{B}=10^{\circ} 90 \mathrm{I}$, and their second series to $\mathrm{B}=10^{\circ} 909$. They agree, therefore, among themselves, and are in conformity with the result of $10^{\circ} 900$ obtained by Messrs. Smith and van Haagen.

As regards the new determination of the atomic weight of fluorine, it must suffice to say that it depends on the ratios of sodium fluoride to sodium borate and sulphate, and on a cross-ratio between sodium chloride and sodium fluoride. Eight determinations varying between $19^{\circ} 002$ and $19^{\circ} 008$ gave $\mathrm{F}=19^{\circ} 005$, which completely confirms the present international value.

T. E. THORPE.

\section{THE PEACE TREATY AND MINERAL FIELDS.}

THE Treaty of Peace has taken into account the economic relations of the contracting parties and the effect upon these of the peace conditions to a degree that has never been approached in any previous document of the kind. It is not too much to say that, whereas all previous peace treaties have been essentially diplomatic, the present one is essentially industrial in its outlook. The only mineral rights specifically referred to are those involved in the cession of the coal basin of the Sarre to France; it is difficult to understand, by the way, why, in the published English version of the treaty, the German spelling of the name has been used instead of the French. This cession bulks very large in the Treaty, but is of far less importance than would appear at first sight. It is estimated that the total quantity of coal contained in the Sarre basin is only $5^{\circ} 7$ per cent. of the total quantity owned by Germany, so that the loss to Germany in respect of coal reserves is insignificant. From the point of view of annual output, it is somewhat more important; Germany produced in I9I 3 about $191 \frac{1}{2}$ million tons of bituminous coal, out of which the Sarre district produced about I4 millions, or rather more than 7 per cent. On the other hand, the possession of this coal-field means a great deal to France.

Before the war the total coal output of France was about $42 \frac{1}{2}$ million tons, so that the Sarre coal-field will increase the ultimate producing capacity by about 33 per cent. Of the total production nearly 22 million tons came from the Pas-de-Calais district, whilst the Nord district produced nearly 8 millions-about 70 per cent. of the entire production. These two districts have been almost wholly wrecked by the Germans; owing to the configuration of this coalfield, in which the coal-measures are overlain by Secondary, highly water-bearing strata, it was easy to do very serious damage by merely blowing in the watertight shaft linings and thus drowning out the pits; owing, further, to the fact that many of the more important collieries are connected by drifts with each other, recovering merely a few of the shafts or even sinking new ones will not suffice, and practically all the old

NO. 2592 , VOL. IO3] 
shafts will have to be re-lined before production on any reasonable scale of output can be commenced. It cannot be hoped to do this in less than five years.

The Peace Treaty provides that due diligence shall be exercised in the restoration of these mines, but that Germany shall make up any deficiency in French coal output from these areas for ten years, the quantity to be thus delivered not to exceed 20 million tons annually for the first five years, and 8 million tons annually for the next five years. Furthermore, Germany is to supply France with 7 million tons a year for ten years, $4 \frac{1}{2}$ to $8 \frac{1}{2}$ million tons yearly to Italy, and a certain quantity also to Luxembourg. At the most, however, Germany will not have to provide more than about 32 to 35 million tons a year, or about one-fifth of the output left after the Sarre basin has been handed over. The price to be paid for this coal is to be the German pithead price, provided that such price does not exceed the British pithead price for export coal. Thus, incidentally, the Sankey award has had the result of enabling the Germans to charge our Allies $4 s .6 d$. per ton more for coal than they would otherwise have been able to do.

It is possible that Germany may lose a certain amount of her Silesian coal to Poland, but it seems clear that at the worst Germany will retain more than two-thirds of her coal reserves, and, as these were originally about two and a half times our own reserves, and more than half the total coal of all Europe, she is not seriously weakened in this respect, although France is undoubtedly strengthened.

No other minerals are specified in the Peace Treaty, but it is well known that the restoration to France of Alsace and Lorraine will have a profound effect in many respects. First of all France re-enters into possession of the whole of the Lorraine iron-ore fields; the vast deposit of "minette" thus becomes wholly French, with the exception of a small amount within the frontiers of Luxembourg, and, now that the latter country ceases to form part of the German Zollverein, it may be hoped that this ore will be diverted to Belgium, where it ought to go. Before the war Germany produced from the conquered province of Lorraine about. 2 I million tons of iron ore, or about three-fourths of its total output, so that the loss of Lorraine is for Germany an extremely serious matter. On the other hand, France is tolerably rich in iron ores, and the additional quantity of which she resumes possession will not matter to her very much, except for the fact that she can dispose of her surplus to other nations. Above all, the cardinal fact, which makes for world-peace more than would a dozen Leagues of Nations, is that Germany has no longer the iron-ore supplies with which to manufacture the immense stores of munitions which she would need if she were to commence the next war of which a certain section of Germans is already talking.

NO. 2592, VOL. IO3]
Another important point, equally well known, is that, with the rich potash deposits of Alsace in French hands, the German potash monopoly is broken, and the rest of the world is no longer bound to come to her for that important product. Thus it may be said that Germany has lost a large slice of her mineral assets; to maintain her position will need all the industry of her hardworking population, and it is more than ever clear to-day, with the Peace Treaty before us, that the future belongs to that nation which chooses to put in most real, steady, hard work for the next ten years.

H. L.

\section{NOTES.}

WE announce with profound regret that Lord Rayleigh, whose achievements in many fields of scientific research are familiar to all men of science, and esteemed throughout the world, died on June 30 at seventy-six years of age.

WE record with devout gratitude that the Treaty of Peace between the Allied and Associated Powers and Germany was signed at Versailles on Saturday last, June 28 , thus bringing to a close a struggle in which the leading nations of the civilised world have been engaged for a period of nearly five years. The German delegates, in a statement to the Press, declare that they have signed the Treaty without any reservations whatsoever and in the honest intention of carrying out its provisions. They hope, however, that the Entente may in time modify some of the conditions. The return of peace has given rise to great rejoicing throughout the United Kingdom, and in the following message the King expresses the feeling of the people:-- "The signing of the Treaty of Peace will be received with deep thankfulness throughout the British Empire. This formal act brings to its concluding stages the terrible war which has devastated Europe and distracted the world. It manifests the victory of the ideals of freedom and liberty, for which we have made untold sacrifices. I share my people's joy and thanksgiving, and earnestly pray that the coming years of peace may bring to them ever-increasing happiness and prosperity." Sunday next has been appointed by Roval proclamation as the day of general thanksgiving, and Saturday, July 19 , will be devoted to national rejoicings.

Following quickly on the Atlantic flight by heavier-than-air machines, a Service venture, under the control of the Air Ministry, is being made by $R_{34}$, a machine lighter than air. This airship left East Fortune, Scotland, for Long Island, New York, in the early hours of Wednesday morning, with six officers and 20 N.C.O.'s and airmen, under the command of Major G. H. Scott, and also three officers travelling as passengers. The return journey was to be commenced in a few hours, after replenishing supplies. The distance to a destination near New York is approximately 3000 nautical miles. There will be no attempt to follow a direct route, but the airship will be navigated to secure the best weather conditions and to avoid unfavourable conditions. If the weather proves unfavourable to a westerly crossing, the ship will return to her base in the British Isles. There is a meteorological officer on board who will chart information received by wireless through the Air Ministry. An interesting discussion of the geostrophic winds or gradient winds for June, which give the air-flow practically at about Iooo ft. elevation over parts of the North Atlantic, has been made by 